\title{
Aplikasi Alkitab Elektronik Perjanjian Baru Bahasa Talaud Berbasis Android
}

\section{Talaud Electronic Bible New Testament Application Based on Android}

\author{
Reynoldus Andrias Sahulata ${ }^{1}$, Frans Mauren Takasanakeng ${ }^{2}$ \\ ${ }^{1,2}$ Fakultas Ilmu Komputer Universitas Klabat \\ Jl. Arnold Mononutu, Airmadidi Minahasa Utara Manado 95371, Sulawesi Utara \\ e-mail: *11 rey_sahulata@unklab.ac.id, ${ }^{2}$ maurenf4@gmail.com
}

\begin{abstract}
Abstrak
Alkitab bahasa Talaud dalam bentuk digital sampai saat ini belum ada, sementara yang menggunakan smartphone sudah sangat masif pada saat ini, sehingga peneliti melihat peluang yang ada dalam mendigitalisasi Alkitab bahasa Talaud perjanjian baru berbasis Android sebagai bentuk apresiasi dalam berbahasa Talaud. Untuk membuat aplikasi ini peneliti menggunakan proses model Spiral yang diawali dengan melakukan komunikasi dengan user untuk mendapatkan informasi, perencanaan untuk menentukan waktu pembuatan, pemodelan dengan menggunakan metode Unified Modeling Language (UML), pengkodean dengan bahasa pemograman Java, dan implementasi dimana aplikasi Alkitab bahasa Talaud ini diuji. Aplikasi ini dibangun dengan menggunakan tools Edraw Max, Eclipse, Android SDK, SQLite. Hasil dari penelitian ini berupa aplikasi Alkitab bahasa Talaud perjanjian baru berbasis Android, yang memiliki fitur kamus, pencarian kata, dan juga pencarian pasal.
\end{abstract}

Kata kunci-Alkitab bahasa Talaud perjanjian baru, Android, Java, smartphone.

\begin{abstract}
The Talaud Bible in digital form until now does not exist yet, while those using smartphones have been massive at this time, so the researcher see the opportunities that exist in digitizing the Talaud Bible New Testament Android-based as a appreciation in the Talaud language. To create this application, the researcher uses a spiral process model that begins by communicating with the user to obtain information, planning to determine time of processing, modeling by using Unified Modeling Language (UML) method, coding with Java programming language, and implementation where this Talaud Bible application is tested. This application was created using the Edraw Max, Eclipse, Android SDK, SQLite. The result of this research is Talaud Bible New Testament application Android-based, which features dictionaries, word searches, and also chapters search.
\end{abstract}

Keywords_-Talaud Bible New Testament, Android, Java, smartphone.

\section{PENDAHULUAN}

Perkembangan teknologi pada saat ini semakin membantu, mendukung dan memberikan kemudahan untuk aktivitas manusia. Ada banyak contoh dari perkembangan teknologi dimana dulu manusia masih membaca lewat buku konvensional dalam bentuk Alkitab [1], namun dalam perkembangannya buku konvensional Alkitab tersebut mulai berkembang menjadi bentuk 
digital yang disertai banyak fitur yang bisa digunakan oleh user untuk memahami isi Alkitab. Dimana media digital tersebut dapat dijumpai pada smartphone.

Keberadaan penggunaan Smartphone pada dewasa ini sudah sangat masif dilihat dari segmentasi penggunanya mulai dari usia yang masih kanak-kanak, remaja, kaum muda, dewasa dan orang lanjut usia.

Fenomena ini menarik untuk dimanfaatkan penggunaanya dengan menyertakan kandungankandungan didalam smartphone tersebut dengan hal-hal yang membangun mental dan spritual bagi pengguna peralatan komunikasi yang selalu dekat dengan penggunanya. Kandungan yang dapat membangun serta meningkatkan mental dan sprital disina adalah dengan adanya kemudah pengguna mendapatkan bahan bacaan yang dapat membimbing kedalam pemahaman akan pentingnya membangun mental dan spritual.

Untuk itu diperlukan suatu sumber yang memiliki kemampuan untuk dapat meningkatkannya yaitu kitab suci. Dalam penelitian ini kitab suci yang akan dihadirkan kedalam kandungan smartphone adalah kitab suci pemeluk agama Kristen yang diterbitkan oleh Lembaga Alkitab Indonesia (LAI), yang menjadi rujukan semua denominasi agama Kristen yang ada dan diakui oleh Pemerintah Indonesi.

Alkitab berisi dalil-dalil yang menyatakan kebenaran mengenai Allah [2]. Alkitab adalah firman Allah yang menghadirkan otoritas Allah dalam kehidupan orang-orang Kristen di dunia, selain itu Alkitab digunakan oleh orang-orang Kristen dalam kehidupan keseharian untuk menuntun kearah nilai-nilai kehidupan yang mempengaruhi keberadaannya sebagai manusia dalam lingkungan kehidupan, dan juga digunakan pada saat acara ibadah sebagai penuntun iman mereka untuk mendekatkan diri pada Tuhan.

Alkitab dituliskan dalam bentuk buku, dimana Alkitab menggunakan berbagai bahasa, dan berbagai bahasa yang telah dicetak salah satunya adalah dengan menggunakan bahasa Talaud, karena bahasa Talaud masih banyak digunakan dalam masyarakat yang ada di provinsi sulawesi utara, hal ini terlihat dari data yang ada, yang disajikan sebagai berikut:

Tabel 1 Masyarakat Yang Mengerti Bahasa Talaud

\begin{tabular}{|c|c|c|}
\hline No & Umur & Persentase \\
\hline 1 & $6-12$ & $30 \%$ \\
\hline 2 & $13-18$ & $65 \%$ \\
\hline 3 & $19-25$ & $75 \%$ \\
\hline 4 & $26-35$ & $82 \%$ \\
\hline 5 & $36-50$ & $95 \%$ \\
\hline 6 & $51+$ & $99 \%$ \\
\hline
\end{tabular}

Sumber Data: Dinas Kependudukan Kabupaten Kepulauan Talaud

Penggunaan Alkitab berbahasa Talaud sangat diperlukan disebabkan dari demografi kependudukan yang ada yang dapat dilihat pada tabel 1.2 yang sumber datanya didapat dari Departemen Agama Kabupaten Kepulauan Talaud yang berisi tentang penjelasan tingkat kepercayaan atau agama yang dianut, terlihat bahwa masyarakat Talaud yang beragama kristen dan katolik memiliki komposisi terbesar dalam masyakat Talaud, yang jika diakumulasikan sebesar 97.2\% membutuhkan Alkitab didalam beribadah dan dalam kehidupan keseharian mereka. Dimana data tersebut diperoleh dari Departemen Agama Kabupaten Talaud yang selengkapnya disajikan sebagai berikut: 
Tabel 2 Jumlah Penduduk Pemeluk Agama Di Kabupaten Talaud Tahun 2016

\begin{tabular}{|c|c|c|c|}
\hline No & Agama & Jumlah Penduduk & Persentase \\
\hline 1 & Kristen & 88.177 & $92.18 \%$ \\
\hline 2 & Katolik & 4.800 & $5.02 \%$ \\
\hline 3 & Islam & 2.682 & $2.80 \%$ \\
\hline Jumlah & & 95.659 & $100 \%$ \\
\hline
\end{tabular}

Sumber Data: Departemen Agama Kabupaten Talaud

Dari kedua tabel tersebut memberikan informasi betapa pentingnya penyediaan Alkitab berbahasa Talaud baik dari sisi penggunaan Alkitab berbahasa Talaud atau pun dari sisi jumlah penduduk yang beragama Kristen dan Katolik dalam hal memenuhi kitab suci mereka. Bagi peneliti keberadan fakta dilapangan yang didukung oleh data yang ada mendorong peneliti untuk menyediakan Alkitab yang dipahami dalam bahasa Talaud dalam bentuk digital yang menggunakan sistem operasi Android.

Berdasarkan statistik laporan hasil riset dari StatCounter yang adalah website analisa statistik, mengenai penggunaan sistem operasi mobile dan tablet selama tahun 2015 sampai awal tahun 2016 di Indonesia memperlihatkan bahwa sistem operasi Android menguasai hampir $70 \%$ pangsa pasar yang ada di Indonesia, sebagaimana yang tersaji pada gambar 1 .

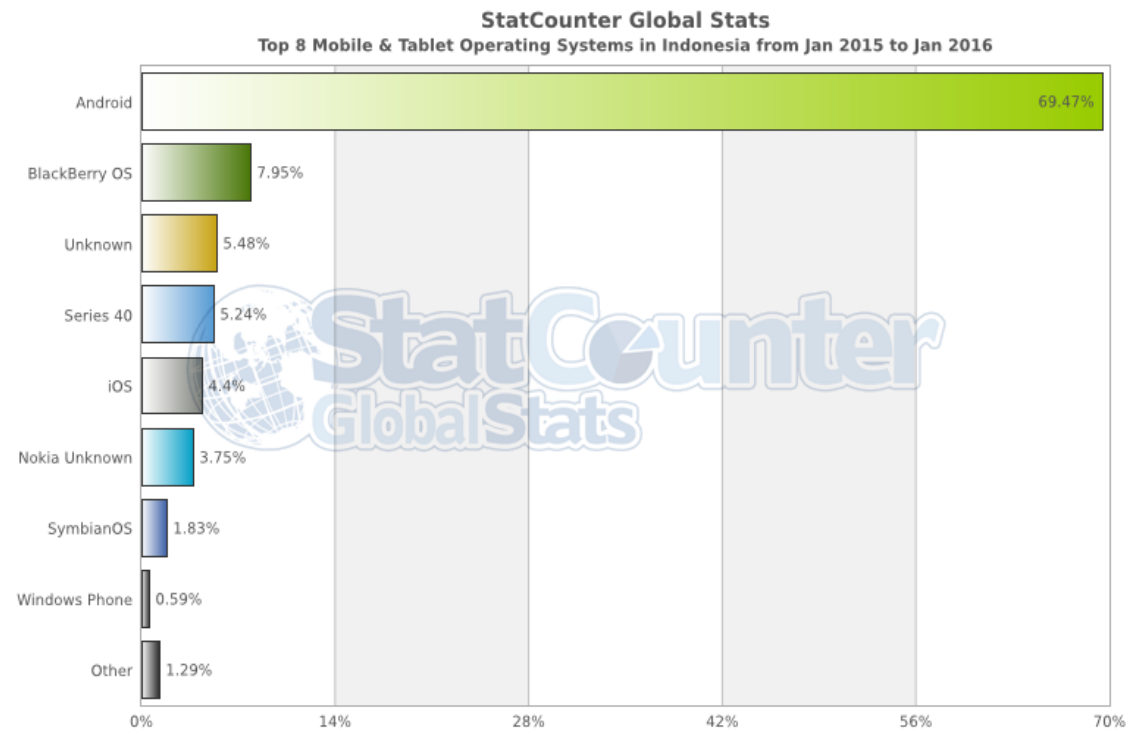

Gambar 1 Statistik Pengguna Sistem Operasi pada Smartphone di Indonesia

Sementara jika dilihat dari pemilihan menggunakan Android sebagai sistem operasi yang bersifat operating system yang paling banyak digunakan. Menurut survei dari IDC Worldwide Mobile Phone Tracker tentang penggunaan operating system mobile Android yaitu $81,0 \%$, iOS 12,9\%, Windows Phone 3,6\%, Blackberry 1,7\%, dan OS lainnya sebesar 0,6\% di seluruh dunia. Beragamnya kelebihan serta kemampuan yang ada pada perangkat smartphone berbasis Android tentu membawa manfaat dan memberikan solusi untuk beberapa keperluan yang dapat kita selesaikan secara mobile dengan efektif [3]. 


\section{METODE PENELITIAN}

Dalam pembuatan aplikasi Alkitab Elektronik, peneliti menggunakan Model Spiral yang merupakan penggabungan dari model Waterfall dan Prototyping [4]. Alasan peneliti menggunakan metode ini karena dapat mengurangi resiko yang mungkin terjadi dan lebih memahami setiap tingkat dari perkembangan aplikasi sebelum melanjutkan ke proses pengembangan selanjutnya.

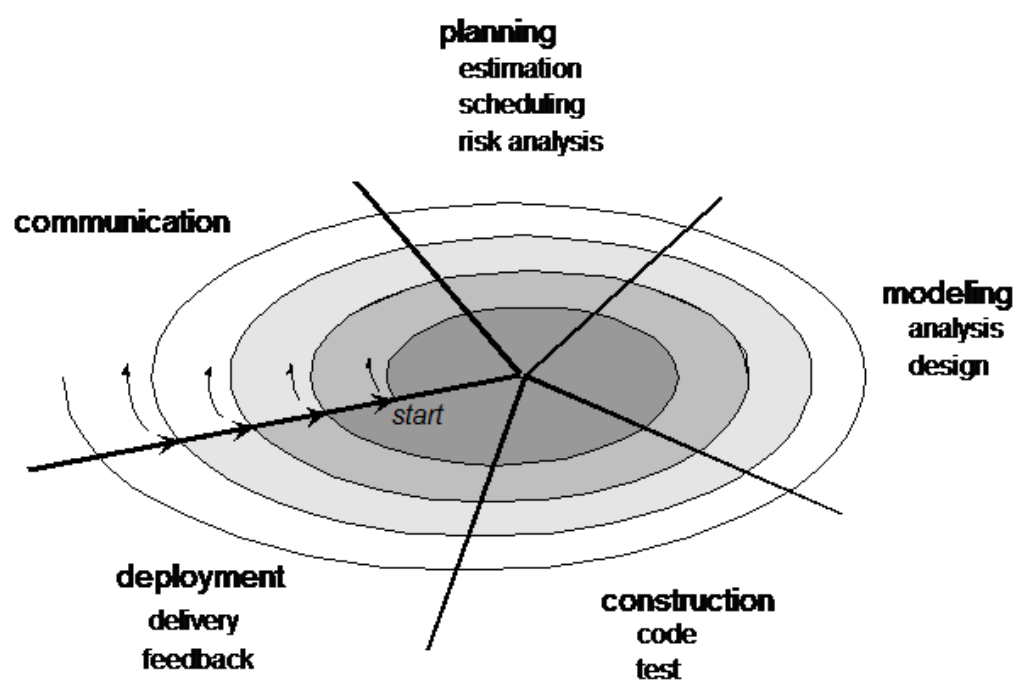

Gambar 2 Model Spiral

1. Communication

Membangun komunikasi antara Developer dengan user dan pengumpulan data sesuai dengan kebutuhan yang diperlukan untuk membangun aplikasi.

2. Planning

Perencaan tentang menentukan fasilitas, waktu pengerjaan, serta informasi lainnya yang terkait denga aplikasi yang dibuat.

3. Modeling

Pembuatan satu atau lebih model untuk aplikasi, dimana model tersebut dapat mewakili aplikasi yang dibangun secara umum.

4. Construction

Pada tahap ini dilakukan pengkodean dan pengujian aplikasi apakah sudah dapat diberikan kepada user.

5. Evaluation

Pengumpulan evaluasi dari user guna mendapatkan feedback untuk aplikasi keseluruhan yang telah dibuat agar dapat lebih bermanfaat [5].

\subsection{Alkitab}

Alkitab adalah sebutan untuk kitab suci umat Kristiani. Walaupun Alkitab itu umumnya dicetak sebagai satu jilid buku dalam dalam berbagai bahasa, sebenarnya merupakan kumpulan dari 66 kitab yang secara resmi diakui oleh umat Kristen sebagai kitab yang diilhami oleh Tuhan Allah.

Kata "Alkitab" berasal dari bahasa Arab, Al dan Kitab, yang secara harfiah berarti "kitab itu" atau "buku itu", di mana kata Al merupakan kata khas dalam bahasa Arab. 
Bagi orang Kristen di Indonesia, istilah "Alkitab" dipakai sebagai sebutan untuk Kitab Suci dalam artian serupa sama seperti Bible dalam bahasa Inggris, yaitu kumpulan Kitab Suci gabungan dari Kitab Suci agama Yahudi yaitu Perjanjian Lama dan kitab-kitab yang ditulis oleh orang-orang Kristen mula-mula yaitu Perjanjian Baru [6].

\subsection{Talaud}

Kepulauan Talaud adalah gugusan pulau-pulau yang berada di utara Indonesia, Secara geografis terletak antara $04^{\circ} 40^{\prime}-05^{\circ} 40^{\prime} \mathrm{LU}$ dan $126^{\circ} 20^{\prime}-127^{\circ} 00^{\prime} \mathrm{BT}$ dan berbatasan sebelah utara dengan Negara Filipina, Sebelah selatan berbatasan dengan laut maluku, sebelah barat bersebelahan dengan laut sulawesi, sebelah timur berbatasan dengan samudra pasifik, Kabupaten Talaud terdiri atas 20 pulau yaitu pulai Karakelang (terbesar), Mangaran, Salibabu, Miangas, Marampit, Karatung, Kakorotan, dan pulau-pulau tidak berpenghuni lainnya. Luas wilayah secara keseluruhan adalah $27.061,16 \mathrm{~km} 2$ yang terdiri dari daratan seluas $1.288,94 \mathrm{~km} 2$ dan lautan seluas 25.772,22 km2 [7].

Kabupaten Kepulauan Talaud adalah salah satu kabupaten di Provinsi Sulawesi Utara, Indonesia dengan ibu kota Melonguane. Kabupaten ini berasal dari pemekaran Kabupaten Kepulauan Sangihe dan Talaud pada tahun 2000. Kabupaten Kepulauan Talaud terletak di sebelah utara Pulau Sulawesi. Wilayah ini adalah kawasan paling utara Indonesia, berbatasan dengan Filipina di sebelah utara. Jumlah Penduduk: 91.067 Jiwa [8].

\section{HASIL DAN PEMBAHASAN}

Pembahasan dibagian ini diawali dengan analisa perancangan aplikasi dengan menggunakan bahasa Unified Modeling Language (UML)

\subsection{Use Case Diagram}

Use Case Diagram merupakan pengambaran interaksi antara user dengan aplikasi dan juga mengambarkan apa yang dapat dilakukan oleh user terhadap aplikasi dan fungsi-fungsi yang dapat dilakukan oleh aplikasi.

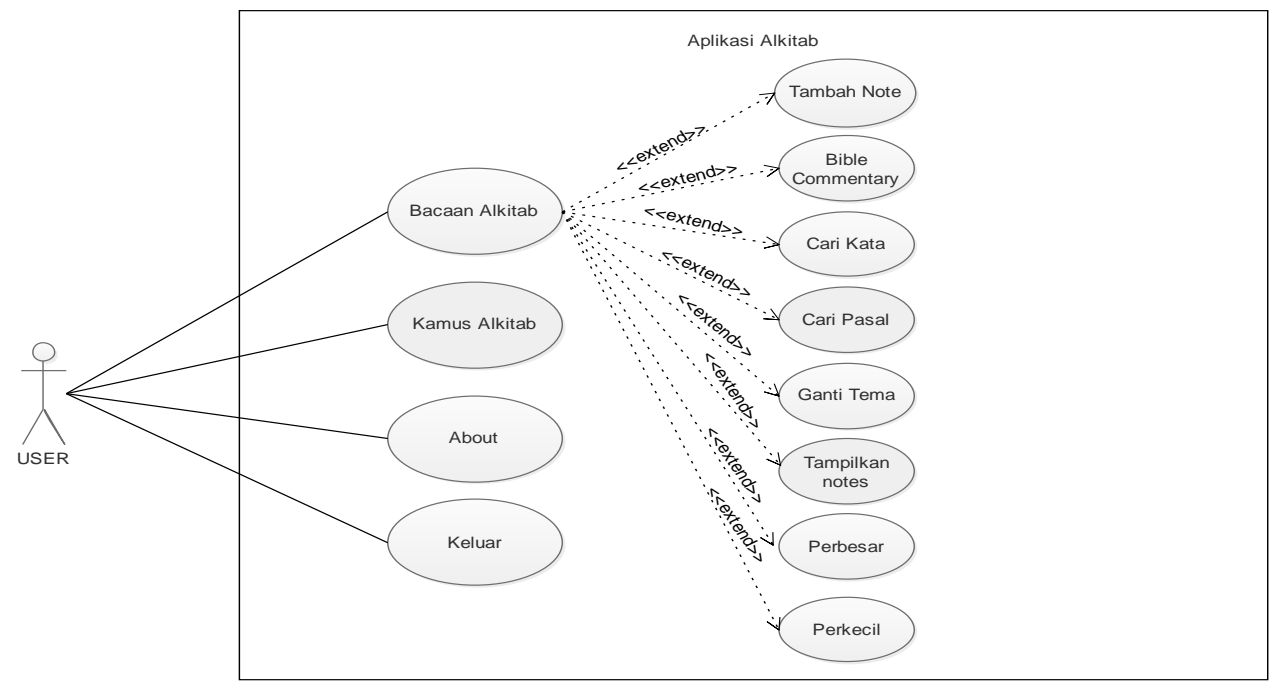

\subsection{Class Diagram}

Gambar 3 Use Case Diagram

Class diagram dipergunakan untuk menampilkan semua kelas yang diperlukan untuk membangun aplikasi dan menggambarkan hubungan antara atribut serta paket-paket yang ada dalam system atau perangkat lunak yang digunakan yang terlihat pada gambar 3 . 


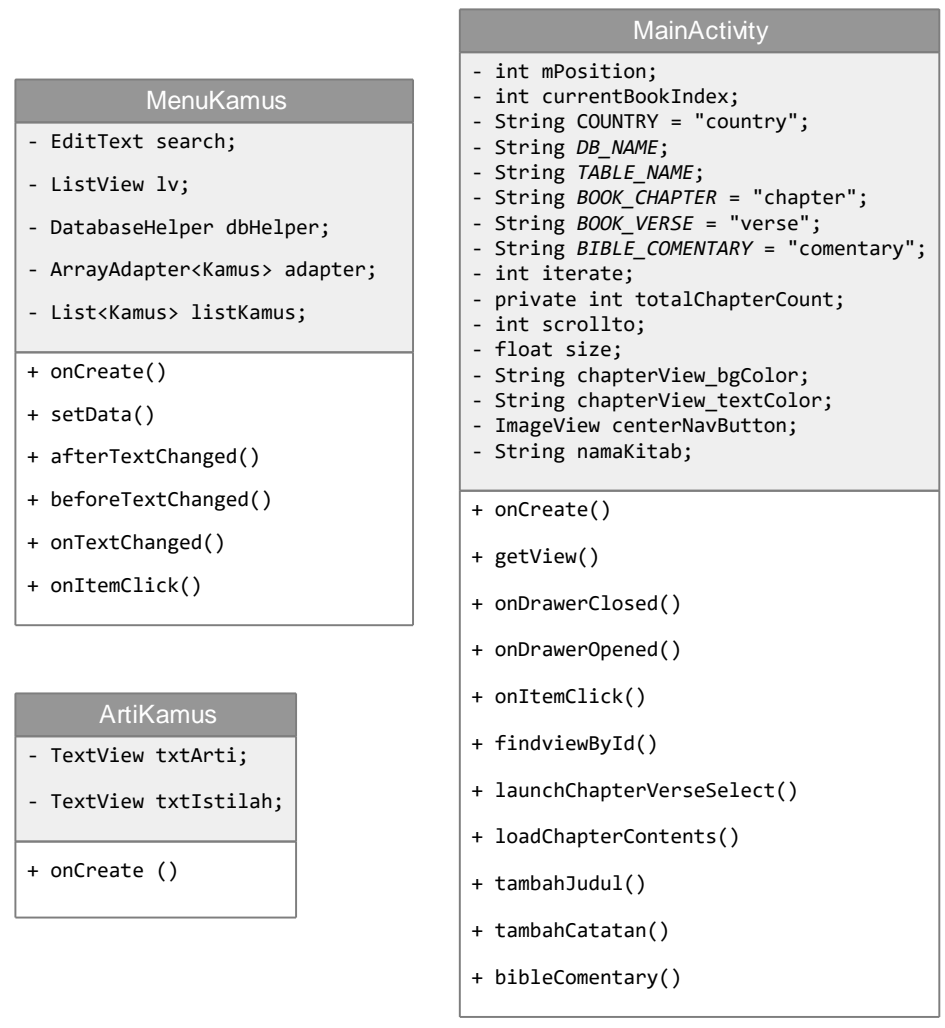

Gambar 4 Class Diagram
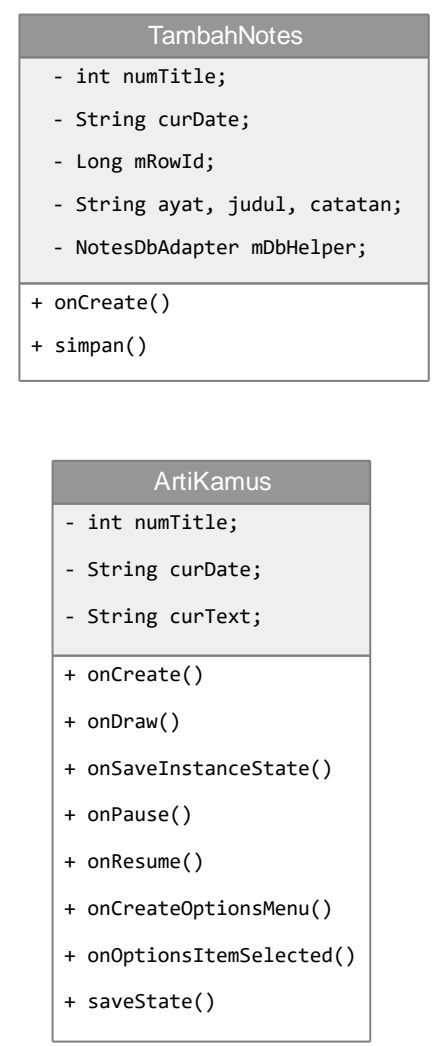

\subsection{Implementasi Database}

Berikut ini merupakan implementasi database dari aplikasi Alkitab bahasa Talaud perjanjian baru.

Tabel 3 Implementasi Database Tabel Alkitab Perjanjian Baru

\begin{tabular}{|l|l|l|l|}
\hline Index & Name & Declared Type & Type \\
\hline 1 & id & INTEGER & INTEGER \\
\hline 2 chapter & INTEGER & INTEGER \\
\hline 3 verse & TEXT & TEXT \\
\hline 4 comentary & TEXT & TEXT \\
\hline
\end{tabular}

Tabel 3 merupakan tabel Alkitab perjanjian baru yang berisi pasal dan ayat yang ada pada perjanjian baru dan juga bible commentary.

Tabel 4 Implementasi Database Tabel Kamus Alkitab

\begin{tabular}{|c|l|l|l|l|}
\hline Index & Name & Declared Type & Type & Size \\
\hline 1 id & INT(10) & INT & 10 \\
\hline 2 nama & TEXT(100) & TEXT & 100 \\
\hline 3 arti & TEXT(1000) & TEXT & 1000 \\
\hline
\end{tabular}

Tabel 4 merupakan tabel kamus Alkitab yang berisi istilah Alkitab beserta dengan arti dari istilah yang dimaksud. 
3.4 Implementasi Pengujian Aplikasi

Tahap pengujian aplikasi merupakan tahap untuk menguji setiap fungsi yang ada pada aplikasi. Pengujian dilakukan oleh peneliti yaitu aplikasi di-instal di device android kemudian setiap fungsi diuji.

Tabel 5 Pengujian Aplikasi

\begin{tabular}{|l|l|l|l|}
\hline Input & Action & Output & $\begin{array}{l}\text { Hasil } \\
\text { pengu } \\
\text { jian }\end{array}$ \\
\hline $\begin{array}{l}\text { Pencari } \\
\text { an kata }\end{array}$ & menekan kolom pencarian & menampilkan hasil pencarian & Sesuai \\
\hline $\begin{array}{l}\text { Pencari } \\
\text { an } \\
\text { Pasal }\end{array}$ & $\begin{array}{l}\text { Menekan tab daftar nama } \\
\text { kitab dan memilih pasal } \\
\text { dan ayat }\end{array}$ & $\begin{array}{l}\text { Menampikan hasil pencarian } \\
\text { berdasarkan pasal dan ayat yang } \\
\text { diinput dan dapat ditampilkan }\end{array}$ & Sesuai \\
\hline $\begin{array}{l}\text { Kamus } \\
\text { Alkitab }\end{array}$ & Menekan menu kamus & $\begin{array}{l}\text { Menampikan hasil pencarian } \\
\text { berdasarkan kata yang diinput dan } \\
\text { dapat ditampilkan }\end{array}$ & Sesuai \\
\hline $\begin{array}{l}\text { Tamba } \\
\text { h notes }\end{array}$ & $\begin{array}{l}\text { Menekan atau tahan bacaan } \\
\text { dan memilih menu notes }\end{array}$ & $\begin{array}{l}\text { Menulis notes dan notes dapat } \\
\text { disimpan }\end{array}$ & Sesuai \\
\hline $\begin{array}{l}\text { Lihat } \\
\text { notes }\end{array}$ & $\begin{array}{l}\text { Menekan menu tampilkan } \\
\text { notes }\end{array}$ & $\begin{array}{l}\text { Menampikan daftar notes dan dapat } \\
\text { ditampilkan }\end{array}$ & Sesuai \\
\hline $\begin{array}{l}\text { Bible } \\
\text { comme } \\
\text { ntary }\end{array}$ & $\begin{array}{l}\text { Menekan atau tahan bacaan } \\
\text { dan memilih menu bible } \\
\text { commentary }\end{array}$ & $\begin{array}{l}\text { Menampikan bible commentary yang } \\
\text { ada pada pasal }\end{array}$ & Sesuai \\
\hline
\end{tabular}

\subsection{Implementasi Aplikasi}

Pada bab ini akan membahas tentang implementasi dari aplikasi Alkitab bahasa Talaud yang dirancang. Implementasi yang dibahas yaitu mengenai implementasi antarmuka.

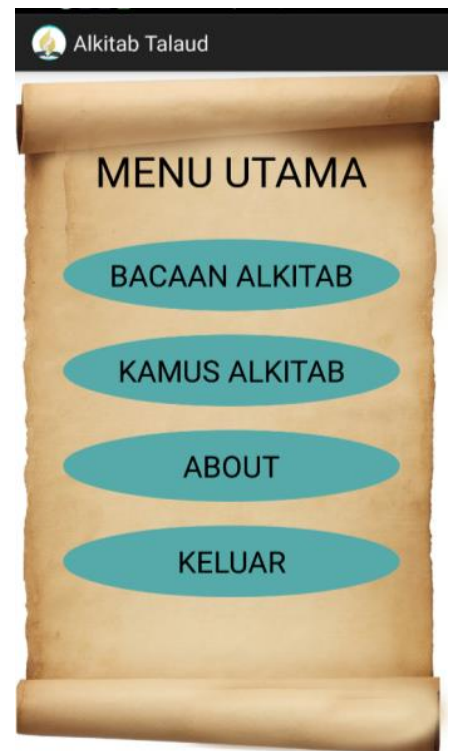

Gambar 5 Implementasi Antarmuka Menu Utama

Gambar 5 merupakan implementasi Antarmuka untuk menu utama pada aplikasi Alkitab bahasa Talaud. 


\begin{tabular}{|c|c|}
\hline$=$ Matius & $Q$ \\
\hline $\begin{array}{l}\text { 1:1 Ete indi arannu iu } \\
\text { Yesus Kristus, papap }\end{array}$ & Kamus Alkitab \\
\hline Abraham. Wuassi $A b$ & Tampilkan Notes \\
\hline 1:2 i Abraham, i Ishal & Ganti Tema \\
\hline 1.3 i Peres wurru i & Perbesar \\
\hline aranne Tamar), i Hez & Perkecil \\
\hline 1:4 i Aminadab, i Nar. & 2..., \\
\hline $\begin{array}{l}\text { 1:5 i Boas (inangngene } \\
\text { (inangngene eteudde } \mathrm{i}\end{array}$ & $\begin{array}{l}\text { e i Rahab), i Obed } \\
\text { Rut), }\end{array}$ \\
\hline $\begin{array}{l}\text { 1:6 i Isai, wurru i Ratu } \\
\text { n sara tempom balaha } \\
\text { su Babel naworretta m } \\
\text { Salomo (inangngene e }\end{array}$ & $\begin{array}{l}\text { Duad Wuassi Daud na'oma } \\
\text { annu Israel nirçuumanna } \\
\text { nangaaranna ereindi: i } \\
\text { teudde inawaluanni Uria), }\end{array}$ \\
\hline 1:7 Rehabeam, i Abia, i & i Asa, \\
\hline 1:8 i Yosafat, i Yoram, i & i Uzia, \\
\hline 1:9 i Yotam, i Ahas, & \\
\hline 1:10 i Hizkia, i Manas & e, i Amon, i Yosia, \\
\hline
\end{tabular}

\section{Gambar 6 Implementasi Antarmuka Menu Pada Bacaan Alkitab}

Gambar 6 merupakan implementasi Antarmuka untuk menu pada bacaan Alkitab yang ada pada aplikasi Alkitab bahasa Talaud.

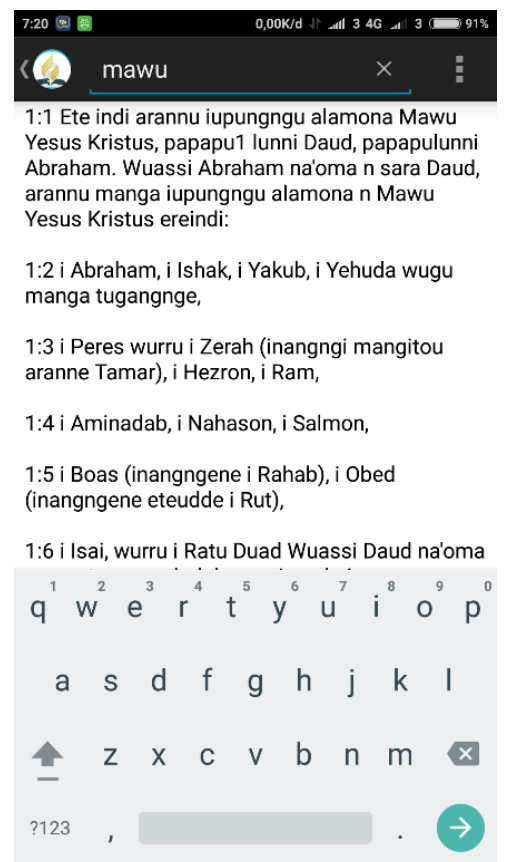

Gambar 7 Implementasi Antarmuka Pencarian Kata

Gambar 7 merupakan implementasi antarmuka untuk pencarian kata. User dapat memasukan kata yang ingin dicari. 
19. Hasil untuk 'mawu'

Matius

1:1 Ete indi arannu iupungngu alamona

Mawu Yesus Kristus, papapu1 lunni Daud,

papapulunni Abraham. Wuassi Abraham

na'oma n sara Daud, arannu manga

iupungngu alamona n Mawu Yesus Kristus

ereindi:

1:2 i Abraham, i Ishak, i Yakub, i Yehuda

wugu manga tugangnge,

1:3 i Peres wurru i Zerah (inangngi

mangitou aranne Tamar), i Hezron, i Ram

1:4 i Aminadab, i Nahason, i Salmon,

1:5 i Boas (inangngene i Rahab), i Obed

(inangngene eteudde i Rut),

1:6 i Isai, wurru i Ratu Duad Wuassi Daud

na'oma $\mathrm{n}$ sara tempom balahannu Israel

nirçuumanna su Babel naworretta

mangaaranna ereindi: i Salomo

(inangngene eteudde inawaluanni Uria),

1:7 Rehabeam, i Abia, i Asa

Gambar 8 Implementasi Antarmuka Hasil Pencarian Kata

Gambar 8 merupakan implementasi antarmuka untuk hasil pencarian kata. User dapat melihat hasil dari pencarian berdasarkan kata yang dimasukan.

\begin{tabular}{|lllll|}
\hline Q Matius & \multicolumn{3}{c|}{ Ayat } \\
\hline Pasal & \multicolumn{5}{c}{} \\
\hline 1 & 2 & 3 & 4 & 5 \\
6 & 7 & 8 & 9 & 10 \\
11 & 12 & 13 & 14 & 15 \\
16 & 17 & 18 & 19 & 20 \\
21 & 22 & 23 & 24 & 25 \\
26 & 27 & 28 & & \\
& & & & \\
\end{tabular}

Gambar 9 Implementasi Antarmuka Menu Pencarian Pasal

Gambar 9 merupakan implementasi antarmuka untuk menu pencarian Pasal. User dapat melihat hasil dari pencarian ayat berdasarkan ayat dan pasal yang di-input. 


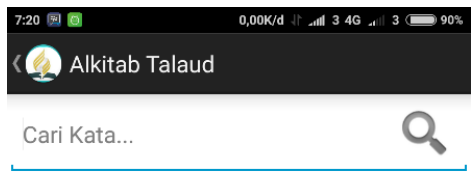

$\mathrm{Ab}$

Abraham

Abram

Adam

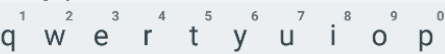

a $s \quad d \quad f \quad g \quad h \quad j \quad k \quad l$

$\begin{array}{llllllllllllllll} & \mathrm{x} & \mathrm{c} & \mathrm{v} & \mathrm{b} & \mathrm{n} & \mathrm{m} & \mathrm{x}\end{array}$

$? 123$

Gambar 10 Implementasi Antarmuka Menu Kamus Alkitab

Gambar 10 merupakan implementasi antarmuka untuk menu kamus Alkitab. User dapat memasukan istilah yang ingin dicari.

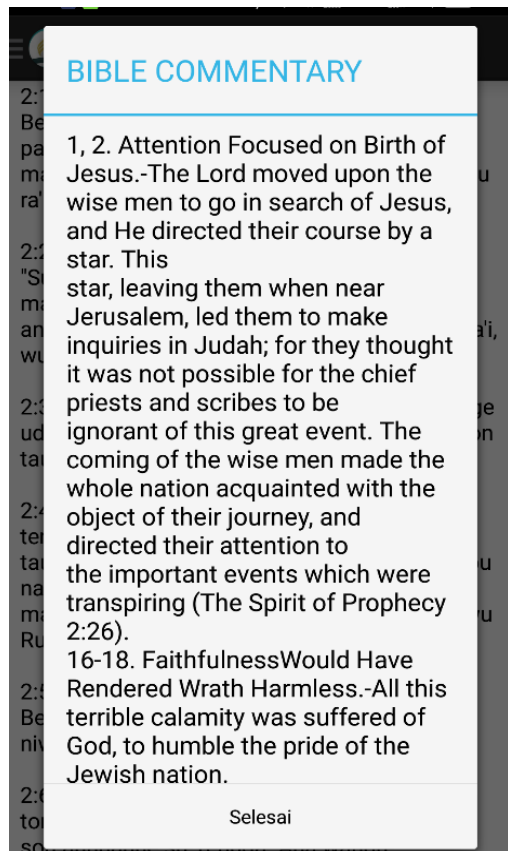

Gambar 11 Implementasi Antarmuka Menu Bible Commentary

Gambar 11 merupakan implementasi antarmuka untuk tampilkan Bible commentary. User dapat melihat Bible commantary pada pasal yang diinginkan. 


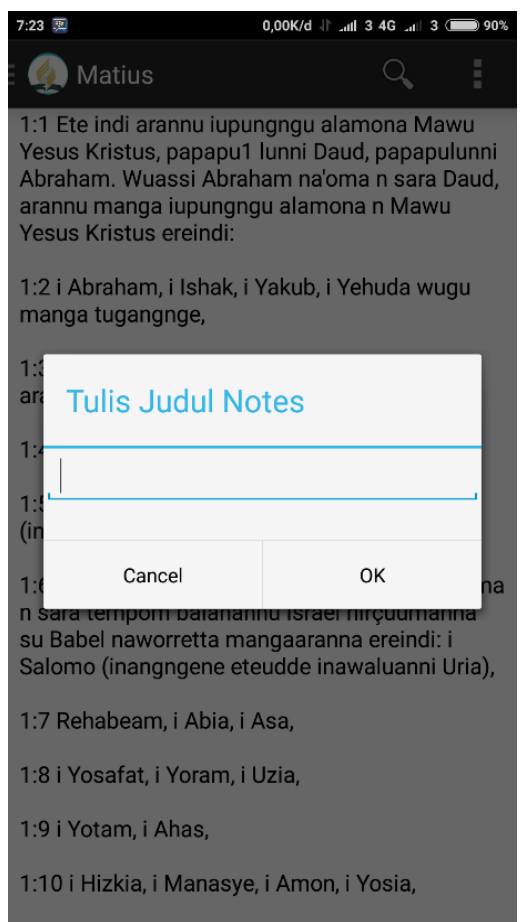

Gambar 12 Implementasi Antarmuka Menu Notes

Gambar 12 merupakan implementasi antarmuka untuk menus notes. User dapat menulis notes pada pasal yang diinginkan.

\section{KESIMPULAN}

Hasil dari penelitian ini dapat disimpulkan bahwa aplikasi Alkitab bahasa Talaud perjanjian baru berbasis Android adalah sebagai berikut :

a. Isinya hanya berupa Alkitab perjanjian baru.

b. Kamus Alkitab yang berisi istilah-istilah yang ada di dalam Alkitab pada perjanjian baru.

c. Pada bagian Bible commentary yang berisi komentar-komentar Alkitab yang ada pada pasal di Alkitab perjanjian baru

d. Pencarian kata yang dapat dipergunakan dalam mencari kata yang ada dalam Alkitab

e. pencarian seluruh pasal yang terdapat pada setiap kitab yang ada didalam perjanjian baru.

f. Tersedia catatan atau notes untuk keperluan pencatatan pada pasal yang diinginkan.

\section{SARAN}

Dalam aplikasi Alkitab perjanjian baru bahasa Talaud peneliti menyadari masih terdapat kurangnya fasilitas atau kemampuan yang dimilki, oleh karena itu peneliti memberikan saran kepada pelitian selanjutnya untuk dapat mengembangkan hal-hal sebagai berikut untuk penyempurnaan dari aplikasi yang sudah ada:

a. Melengkapi bagian Alkitab perjanjian lama

b. Melengkapi aplikasi Alkitab bahasa Talaud dengan terjemahan dalam bahasa Indonesia

c. Menambahkan aplikasi dengan peta dunia perjanjian baru.

d. Dapat menampilkan ayat yang dicari.

e. Pada bagian Bible commentary dilengkapi dengan bahasa Indonesia atau bahasa Talaud. 


\section{UCAPAN TERIMA KASIH}

Peneliti mengucapkan terima kasih kepada Bapak Jerry Takasanakeng yang sangat berkontribusi dalam penelitian ini dalam membantu penyediaan data terlebih dalam hal penyandang dana penelitian ini.

\section{DAFTAR PUSTAKA}

[1]. M. S. Lumowa, dan C. V. R. Malope, "Aplikasi Mobile Lagu Sion Edisi Lengkap Berbasis Android," Skripsi, Universitas Klabat, 2015.

[2]. W. Nadeak, dan D. Sinaga, Apa Yang Perlu Anda Ketahui Tentang 28 Doktrin, Bandung: Indonesia Publishing House, 2006.

[3]. Lolong, S., Lalamentik, M. D. dan Kindangen J,. Aplikasi Kamus Penyakit Manusia Berbasis Android. Cogito Smart Journal, No. 2, Vol. 2, 272-285, Desember 2016.

[4]. Tirayoh. A, Meddelu. S, Sahulata. R. A,. Aplikasi Alat Musik Tradisional Totobuang Berbasis Android. Cogito Smart Journal, No. 1, Vol. 1, 68-77, Desember 2015.

[5]. Thomson. B, "Boehm's Spiral Revisited," [Online] Available: http://leansoftwareengineering.com/2008/05/05/boehms-spiral-revisited/. [Accessed 5 Februari 2016].

[6]. "Wikipedia,". [Online]. Available: https://id.wikipedia.org/wiki/Alkitab. [Accssed 5 Februari 2015].

[7]. "Kemendesa," [Online]. Available: http://www.kemendesa.go.id/profildaerah/34/kabupaten-kepulauan-talaud. [Accessed 6 Februari 2016].

[8]. “Antarasulut," [Online]. Available: www.antarasulut.com/berita/12797/profilkabupaten-kepulauan-talaud. [Accessed 6 Februari 2016]

[9]. S. N. M. Rachman, "Sistem informasi Geografis Parawisata Kota Yogyakarta Berbasis Mobile Android 2.2," Amikan, 2012.

[10]. Widiyantoko. D42112264. Google Android : Structure, Kernel system, Memory management, Security. Universitas Hasanuddin, 2014. 